\title{
TRANSFORMASI MANAJEMEN MADRASAH
}

\author{
Barnawi \\ Dosen Tetap Program Studi PGSD STKIP Islam Bumiayu
}

\begin{abstract}
Madrasah as an Islamic education institute occupies a strategic position in the intellectual life of the nation's efforts. Unfortunately, such a strategic position hasn't been fully utilized so far. The indicators are the madrasah has not been the first choice of primary and community education service users. The cause is that the madrasah has not shown a capacity as a good quality institution in a competitive and comparative ones. Transformation of madrasah management can refer to two fundamental questions that is what is doing wrong and what action needs to be done to make better madrasah. From the transformation carried out, the aim is madrasah institutions that have brand in the hearts of the people. By the brand, the madrasah is expected to be first and foremost choice of the community education service users.
\end{abstract}

Keywords: Transformation and Madrasah Management.

\section{Pendahuluan}

Madrasah sebagai embrio pendidikan pribumi di Tanah Air menempati posisi strategis dalam upaya mencerdaskan kehidupan bangsa. Sinergisitas corak kepesantrenan dan pendidikan formal tidak saja membekali peserta didik knowledge (pengetahuan) yang cukup, tetapi juga membentuk peserta didik dengan perilaku (bebavior) yang relatif baik. Dalam perspekif hukum madrasah merupakan sekolah yang berciri khas agama Islam (PP No 28 Tahun 1990 dan PP No. 29 Tahun 1990). Dalam UU No. 20 Tahun 2003 madrasah disetarakan dengan sekolah umum.

Dengan status baru sebagai institusi yang setara dengan sekolah umum diharapkan madrasah mendapatkan perlakuan yang sama dalam sistem pendidikan nasional secara penuh. Integrasi madrasah ke dalam sistem pendidikan nasional bukan berarti peleburan total atau model pengelolaan satu atap di bawah Kementerian Pendidikan Nasional, namun lebih pada pengakuan bahwa madrasah adalah bagian dari sistem pendidikan nasional.

Pengakuan madrasah sebagai bagian yang tidak terpisahkan dari sistem pendidikan nasional secara hukum tampak setelah Undang-undang No. 2 
tahun 1989 tentang Sistem Pendidikan Nasional diratifikasi. Pengakuan tersebut secara eksplisit termaktub dalam UU No. 20 Tahun 2003 tentang Sistem Pendidikan Nasional dan PP No. 19 Tahun 2005 tentang Standar Nasional Pendidikan.

Dengan status yang sama dengan sekolah umum, madrasah harus berevolusi dan mentransformasikan diri untuk menjadi sekolah yang memiliki keunggulan kompetitif dan keunggulan komparatif. Keunggulan kompetitif mencakup ranah akademik dan delapan Standar Nasional Pendidikan, sedangkan keunggulan komparatif mencakup keunggulan pembeda yang tidak dimiliki institusi lain.

Belakangan eksistensi madrasah mulai dibanding-bandingkan dengan sekolah umum yang oleh masyarakat diasumsikan lebih menjanjikan dari sisi kualitas pendidikan. Asumsi, stigma, dan apapun namanya adalah opini yang perlu dicermati. Membicarakan madrasah sama halnya dengan membicarakan institusi/lembaga Islam yang menyelenggarakan pendidikan formal. Dan apapun yang namanya institusi/lembaga dalam perspektif Arie de Geus (dalam Kasali, 2006) merupakan sosok makhluk hidup (a living organism). Sebagai sosok makhluk hidup, maka eksistensinya suatu saat akan sakit, tua, bahkan mati.

Dalam kaca mata usia, madrasah yang telah lama ada digolongkan sebagai sosok makluk hidup yang telah tua. Karena usianya yang telah tua, madrasahpun tak dapat menghindar dari penyakit tua. Dalam usianya yang tua yang dibutuhkan adalah individu-individu yang membuat madrasah berjiwa muda, berpenampilan dewasa (bukan tua), dan perawatan yang baik agar fresh dan berenergi. Dalam konteks ini diperlukan transformasi manajemen madrasah, dari manajemen tradisional ke manajemen modern, dari pendekatan jadul ke pendekatan kekinian.

\section{Konsep Dasar 'Transformasi}

Perubahan adalah sunnatullah. Dalam realitas yang senantiasa berubah, adaptasi merupakan langkah strategis bagi individu dan sistem apapun untuk dapat melangsungkan eksistensinya. Dalam pepatah Romawi dikenal istilah: crescit in cundo, bertumbuh selagi berjalan. Dalam arti yang lebih luas, perubahan adalah esensi dan pertanda kehidupan (Abdullah, dalam 
Kasali, 2005). Transformasi atau perubahan memerlukan perhitungan yang matang. Transformasi merupakan pilihan sikap yang by desain, dengan memperhitungkan potensi, kelemahan, peluang, dan ancaman potensial. Dengan demikian transformasi memerlukan pendekatan, baik pendekatan ilmiah, kultural, dan yang pasti adalah pendekatan manajerial karena pada hakikatnya setiap perubahan memerlukan manajemen perubahan.

Rudjito mengurai transformasi kedalam empat sisi yakni transformasi manajemen, transformasi strategi, transformasi struktural, dan transformasi budaya. Namun demikian, Rudjito menekankan keempatnya harus dijalankan secara seimbang dan beriringan (http://www.itb.ac.id/ news/2135.xhtml). Rudjito juga menandaskan bahwa transformasi berbeda dengan perubahan. Jika perubahan dapat terjadi dalam skala kecil, sedang maupun besar, transformasi adalah perubahan dan pergeseran fundamental. Perubahan transformasional membutuhkan kepemimpinan yang mampu memberikan inspirasi, berkharisma, dan memperhatikan setiap individu.

Menurut Kasali (2005) transformasi biasanya dilakukan oleh perusahaan-perusahaan yang sehat, atau perusahaan-perusahaan yang mulai menangkap adanya signal-signal yang kurang menggembirakan. Dalam transformasi ada dua pertanyaan mendasar yang menjadi acuan, pertama; tindakan-tindakan salah apa yang telah dilakukan, dan yang kedua; tindakan apa yang perlu dilakukan untuk menjadi lebih baik. Dalam transformasi manajemen tidak saja dibutuhkan keterampilan dan strategi baru, tetapi juga menyangkut kepemimpinan dari suatu organisasi, kemampuan berfikir dan bertindak, serta kecerdasan mengambil keputusan. Transformasi di dalamnya juga bertujuan mengubah budaya untuk mempertahankan jenisjenis pendekatan yang dituntut hari ini dan yang bisa mengubah besok.

Dari pemikiran dan terminologi tentang transformasi manajemen dapat ditarik kesimpulan bahwa transformasi manajemen merupakan perubahan dan pergeseran fundamental dalam pengelolaan yang dilakukan dengan terencana, menggunakan multi pendekatan, dan berangkat dari refleksi realitas yang ada sebagai pijakan menentukan langkah strategis ke depan dalam bertindak dan mengambil keputusan. 


\section{Manajemen Madrasah}

Manajemen pada dasarnya merupakan suatu proses penggunaan sumber daya secara efektif untuk mencapai sasaran atau tujuan tertentu (Muhaimin, dkk, 2009). Dalam konteks manajemen madrasah, penggunaan sumber daya secara efektif bertujuan untuk merealisasikan visi setiap madrasah melalui misi madrasah. Dengan demikian orientasi dari sebuah manajemen berangkat dari sebuah visi yang dikonkritkan melalui misi. Manajemen sebuah perusahaan tentu berorientasi pada satu hal yakni profit (keuntungan) yang ditembuh dengan langkah taktis perusahaan. Sama halnya dengan manajemen sebuah madrasah, orientasi yang pertama dan utama adalah perwujudan manusia yang memiliki ilmu dan keterampilan berlandaskan ajaran Agama Islam.

Terlepas dari orientasi nonprofit, sebagai sebuah institusi madrasah sejatinya merupakan perusahaan yang mulia (noble industry) yang tentu saja memiliki orientasi profit sebagai upaya tumbuh dan berkembang. Dalam konteks upaya memperoleh keuntungan, maka efisiensi dan efektifitas merupakan pilihan langkah yang jamak dipilih. Dalam sistem manajemen modern, setiap organisasi berpijak pada empat langkah sistematis yang disebut dengan planning, organizing, actuating, dan controlling. Berpijak dari uraian di atas, kesimpulan penting yang diambil adalah bahwa transformasi manajemen madrasah merupakan perubahan dan pergeseran fundamental dalam planning, organizing, actuating, dan controlling dari setiap pilihan program yang akan dilakukan sebagai upaya perwujudan lembaga yang efektif dan efisien dalam bekerja untuk mencapai visi madrasah.

\section{Kondisi Madrasah secara Makro}

Khaeruddin dan Mahfud Junaidi (2007) menyatakan kondisi riil madrasah saat ini dapat dilihat dari 8 standar Nasional Pendidikan, sebagai berikut:

1) Standar isi: secara keseluruhan madrasah sudah melaksanakan standarisasi pelaksanaan kurikulum. Ketidakmerataan pemahaman pengelola madrasah menyebabkan ketidaksamaan dalam mengimplementasikan kurikulum tersebut. 
2) Standar proses; dalam pembelajaran, guru-guru masih menerapkan pola lama, one man show, tidak sesuai dengan tutntutan KTSP yang menekankan pembelajaran aktif.

3) Kompetensi lulusan: dari sisi kualitatif masih tertinggal dilihat dari distribusi ke perguruan tinggi, penguasaan keilmuan, dan keterampilan.

4) Pendidik dan tenaga kependidikan; tenaga pendidik telah mencukupi, yang belum mencukupi adalah tenaga kependidikan seperti TU, laboran, dan pustakawan.

5) Sarana prasarana; madrasah negeri telah standar, sebagaian madrasah swasta berjalan seadanya.

6) Standar pengelolaan madrasah; dalam pengelolaan madrasah sebagian besar belum mampu menerapkan MPMBM (Manajemen Peningkatan Mutu Berbasis Madrasah).

7) Pembiayaan; khusus untuk madrasah swasta semua biaya investasi menjadi tanggungan madrasah atau yayasan pengelola.

8) Standar penilaian pendidikan; masih terjadi disparitas kualitas penilaian antarmadrasah.

\section{Kondisi Madrasah secara Mikro}

Dalam kaca mata penulis transformasi manajemen madrasah merupakan hal yang mendesak untuk dilakukan. Hal ini disebabkan oleh beberapa faktor yang merupakan kondisi mikto madrasah, yakni:

1) Madrasah (swasta) sampai saat ini banyak dikelola oleh yayasan yang dimiliki perseorangan (one man show), meskipun dalam akta yayasan terdiri atas beberapa pengurus namun dalam faktanya madrasah adalah milik seseorang yang memiliki big picture dalam yayasan tersebut.

2) Adanya indikasi pola pengelolaan madrasah tidak ubahnya industri rumah tangga dan telah bergeser dari institusi sosial keagamaan menjadi mesin uang bagi yayasan.

3) Pola rekruitmen tenaga pendidik dan kependidikan syarat dengan koneksi, tanpa melalui fit and proper test atau uji kompetensi.

4) Pola hubungan yayasan dan karyawan tidak ubahnya hubungan antara pemilik modal dan pekerja sehingga pola patron-klien sangat tampak. 
5) Standarisasi tidak diberlakukan secara ketat sehingga terkesan just flow.

\section{Hasil 'Transformasi Yang Diharapkan}

Upaya transformasi manajemen madrasah, hal yang diharapkan adalah sebagai berikut:

1) Dengan transformasi manajemen, diharapkan kurikulum tertata dengan baik. Artinya standar isi yang digariskan baik melalui Permendiknas No 22 Tahun 2006 maupun Permenag No 2 Tahun 2008 dapat dipahami oleh stakeholder madrasah. Memahami berarti dapat menganalisis anatomi kurikulum sehingga berdampak pada profesionalisme guru madrasah yang muaranya adalah membekali siswa pengetahuan, sikap, dan keterampilan siswa sesuai standar isi yang digariskan.

2) Menyelenggarakan proses pembelajaran dengan tepat. Proses pembelajaran yang tepat adalah proses pembelajaran yang tidak bias. Memiliki standarisasi dalam pembelajaran, artinya siklus materi, kompetensi, strategi, dan evaluasi dilaksanakan secara linier. Proses pembelajaran tidak sekedar mentransfer knowledge ke peserta didik, tetapi memberi argumen atas ontologi, epistemologi, dan aksiologi materi pelajaran. Tujuannya adalah terbentuk mentalitas kritis siswa terhadap kajian ilmu pengetahuan dan membangun scientific curiousity pada diri siswa.

3) Memenuhi standar kompetensi lulusan. Transformasi manajemen madrasah dalam ranah kompetensi lulusan diperlukan standarisasi yang tidak saja dalam wilayah Permendiknas No 22 'Tahun 2006, tetapi juga standarisasi kompetensi lulusan sesuai dengan Permenag No 2 Tahun 2006. Kompetensi lulusan madrasah tidak saja mata pelajaran yang di-Ujian Nasional-kan, tetapi juga ada standarisasi yang ketat dalam pengetahuan agama. Ini penting agar lulusan madrasah memiliki keunggulan komparatif dibanding sekolah umum.

4) Memenuhi standar pendidik dan kependidikan. Standar pendidik dan tenaga kependidikan madrasah yang perlu dicermati adalah kurangnya tenaga teknis baik tenaga teknis administrasi, laboran, pustakawan, atau teknisi bengkel (untuk madarsah keterampilan). Minimnya tenaga teknis ini menjadikan tata kelola kegiatan dan program 
yang bersifat teknis tidak berjalan dengan baik. Tenaga kependidikan yang diharapkan ke depan adalah tenaga professional sesuai dengan wilayah teknis tugasnya. Stakehoder madrasah tidak perlu menunggu uluran tangan dari Kementeraian Agama untuk mengadakan tenaga teknis tersebut, manajemen madrasah harus segera mengadakan dengan cara rekruitmen dari lulusan pergurun tinggi yang linier dengan bidang tugasnya, atau menyekolahkan alumni yang diproyeksikan untuk menempati pos yang diperlukan.

5) Memiliki sarana dan prasarana yang standar. Sarana dan prasarana merupakan instrumen mutlak yang harus dimiliki oleh madrasah. Pola asal jalan harus dihindari oleh pengelola madrasah. Ini penting karena selama ini madrasah (terutama madrasah swasta) membelanjakan bantuan tidak berdasarkan analisis kebutuhan tetapi hanya berorientasi pada bangunan fisik dengan mengesampingkan faktor lain yang justru akan menunjang kualitas madrasah. Banyak madrasah yang memiliki banyak gedung, tetapi sarana lain seperti perpustakaan, buku-buku, laboratorium, media pembelajaran, dan jaringan internet tidak ada. Manajemen madrasah penulis cermati sampai saat ini berorientasi pada jumlah bangunan yang dimiliki dengan harapan memperoleh siswa yang banyak karena ruang kelas yang banyak. Dengan siswa yang banyak diharapkan memperoleh profit yang banyak pula. Pola pengelolaan madrasah yang menekankan kuantitas dengan mengesampingkan kualitas mestinya dihindari karena justru akan merugikan madrasah.

6) Adanya standar pengelolaan yang baik. Standar pengelolaan yang baik berangkat dari perencanaan yang baik, pengorganisasian madrasah yang baik, pelaksanaan program yang baik, dan evaluasi diri yang baik. Siklus ini jarang diperhatikan oleh pengelola madrasah sehingga ketiadaan standar tata kelola. Instansi vertikal memang telah berupaya menggiring madrasah untuk melaksanakan perencanaan madrasah yang baik dengan program pembuatan Renstra beramai-ramai dalam suatu workshop manajemen madrasah. Akan tetapi Renstra itu seringkali berakhir jadi arsip madrasah dan hanya digunakan sebagai bukti administratif dalam akreditasi madrasah. Transformasi pengelolaan ini penting dan menjadi ruh dari semua transformasi madrasah.

7) Memenuhi standar pembiayaan. Secara umum problem klasik madrasah 
adalah minimnya keuangan yang dimiliki. Banyak madrasah yang "bidup segan mati tak mau' karena ketiadaan dana segar untuk operasional dan mengambil langkah-langkah strategis untuk segera beranjak menjadi madrasah yang berkualitas. Madrasah, jika ingin maju seharusnya memiliki dana abadi atau bentuk usaha yang dapat menunjang perkembangan madrasah. Madrasah yang tergopoh-gopoh karena ketiadaan uang harus segera mengambil langkah strategis. Madrasah dapat mengajukan profit sharing kepada pihak yang mampu, atau cara lain yang mungkin dapat ditempuh misalnya dengan pola konsorsium dengan melibatkan pihak ketiga. Ke depan yang penulis harapkan adalah ; tidak boleh ada madrasah miskin.

8) Memenuhi standar penilaian. Penilaian dalam kaca mata penulis tidak sebatas pada penilaian proses dan hasil belajar peserta didik. Penilaian dalam konteks ini juga menyangkut penilaian institusi oleh para outsider baik itu Badan Akreditasi Sekolah/Madrasah, tetapi juga penilaian oleh masyarakat. Adanya transformasi madrasah ini diharapkan penilaian proses dan hasil belajar dilaksanakan dengan professional dengan mengacu pada prinsip-prinsip penilaian, sedangkan secara instritusional madrasah dinilai sebagai lembaga pendidikan yang capable, lebih dari sekedar sekolah biasa.

Dengan melebihi delapan Standar Nasional Pendidikan diharapkan madrasah memiliki branded yang kuat. Untuk menjadi isnstitusi yang memiliki branded yang melekat dalam pikiran masyarakat, maka madrasah harus membangun kultur crackers. Menurut Kasali (2011) kultur crackers meliputi: mengubah wajah industri, menembus segala hambatan, rela bekerja keras dan mendengarkan hal-hal yang baru, bongkar cara berfikir lama, know yous self, your costumer \& your competitior, terbuka terhadap gagasangagasan baru, beradaptasi secara radikal, menciptakan hal-hal baru, ambil segala resiko, dan ukur kapan perubahan radikal menyentuh. Ke depan yang diharapkan adalah madrasah menjadi pilihan pertama dan utama dari masyarakat pendidikan di Tanah Air. Ibaratnya; jika orang bicara motor akan menyebut HONDA, jika bicara pompa air akan menyebut SANYO, jika bicara lampu akan menyebut PHILIPS, dan jika bicara sekolah akan menyebut MADRASAH. 


\section{Penutup}

Transformasi manajemen madrasah dapat merujuk pada dua perubahan manajemen yakni perubahan operasional dan perubahan strategis. Perubahan operasional merupakan perubahan-perubahan kecil yang sifatnya parsial (Kasali, 2006). Dalam konteks madrasah perubahan parsial dapat berupa perubahan desain kurikulum, seragam sekolah, dan penampilan madrasah. Munculnya banyak sekolah yang uniform-nya mirip tentara merupakan strategi operasional yang bersifat parsial. Madrasah dalam perubahan operasional dapat melakukan dekonstruksi kurikulum atas dasar filosofi KTSP, dan redesain tata organisasi madrasah agar lebih smart.

Perubahan strategis (strategic change) mengarah pada tiga perubahan mendasar yang meliputi perubahan budaya dan nilai, perubahan arah/ fokus, dan perubahan cara kerja. Dalam perubahan budaya (shift culture) tidak boleh tercerabut dari lingkungan madrasah dengan corak dasar kepesantrenan. Budaya unggul yang perlu ditanamkan adalah budaya equalitas (kesamaan) tanpa memandang nasab siapa sehingga kesenjangan kasta dan pengkultusan individu tereduksi. Budaya ilmiah dengan penemuan, inquiri, dan pendekatan berbasis masalah harus lebih ditanamkan.

Perubahan arah berorientasi pada keunggulan komparatif yang dibangun. Sebagai sekolah umum yang berciri khas agama madrasah tidak cukup memenuhi standar nasional pendidikan, tetapi harus lebih sebagai keunggulan komparatif yang dimiliki. Ibarat orang jualan, jika semua menjual kecap, maka madrasah harus menjual saos agar tetap diburu pembeli, sebab penjual kecap semuanya mengklaim kecapnya nomor satu. Keunggulan komparatif dapat dibangun dengan basis dua model, model pertama penguatan pada kitab turats dan model kedua pada diversifikasi pendekatan pembelajaran dan life skill untuk menghasilkan lulusan yang kuat dalam keilmuan dan memiliki skill yang pragmatis.

Perubahan strategis yang ketiga adalah perubahan cara kerja untuk meningkatkan efisiensi dan penghasilan dengan memanfaatkan sumber daya yang ada. Dalam peningkatan penghasilan yang perlu dilakukan stakeholder madrasah adalah membentuk tin fundrising madrasah. Tugas tim fundrising madrasah adalah mengakses dana dan menggali dana baik dari pihak luar (donator, zakat pendidikan, dana APBN/APBD, CSR 
dari perusahaan) atau dana yang diperoleh melalui usaha yang dimiliki madrasah.

Dalam perubahan cara kerja yang dibutuhkan oleh pengelola madrasah adalah bagaimana setiap kerja terukur, tidak sekedar berjalan apa adanya. Kerja terukur membutuhkan parameter atau standarisasi. Ini penting dilakukan agar setiap pekerjaan yang dilakukan ada ruh dan semangat kerja. Ruh dan semangat kerja menandakan kinerja yang sungguh - sungguh yang akhirnya bermuara pada hasil yang maksimal, man jadda wa jadda.

\section{DAFTAR PUSTAKA}

Kasali, R. 2005. Change. Jakarta: Gramedia.

Kasali, R. 2011. Cracking Zone. Jakarta: Gramedia.

Khaeruddin, J. M., 2007. KTSP: Konsep dan Implementasinya di Madrasab. Yogyakarta: Pilar Media.

Muhaimin, dkk., 2005. Manajemen Pendidikan: Aplikasinya dalam Penyusunan Rencana Pengembangan Sekolab/Madrasab. Jakarta: Kencana http://www.itb.ac.id/news/2135.xhtml 